\title{
HUBUNGAN MINAT DAN TINGKAT PERHATIAN ORANG TUA DENGAN HASIL BELAJAR IPS PESERTA DIDIK DI SMP NEGERI 6 PALANGKA RAYA
}

\author{
ENDANG SRI SUYATI \\ Dosen Pada Fakultas Keguruan Dan Ilmu Pendidikan Program Studi Pendidikan Ekonomi \\ Universitas Muhammadiyah Palangkaraya
}

\begin{abstract}
ABSTRAK
Penelitian ini bertujuan untuk mengetahui hubungan minat dan tingkat perhatian orang tua dengan hasil belajar IPS peserta didik di SMP Negeri 6 Palangka Raya.

Metode penelitian yang digunakan dalam penelitian ini adalah metode korelasional. Dalam penelitian ini jumlah populasi peserta didik kelas VIII sebanyak 252 orang. Maka peneliti mengambil sampel sebanyak 152 orang peserta didik. Sehingga dalam penelitian ini disebut penelitian sampel. Variabel dalam penelitian ini ada 3 (tiga) variabel yaitu variabel bebas minat dan tingkat perhatian orang tua, sedangkan variabel terikat adalah hasil belajar IPS. Teknik pengumpulan data menggunakan teknik angket dan tes, dan teknik analisis menggunakan analisis korelasi ganda.

Dari analisis data diperoleh hasil penelitian (1) Ada hubungan positif antara minat belajar dengan hasil belajar IPS peserta didik, dengan koefisien korelasi $r X 1 Y=0,521$. Korelasi tersebut signifikan pada populasi. (2) Ada hubungan positif antara tingkat perhatian orang tua dengan hasil belajar IPS peserta didik, dengan koefisien korelasi $r X 2 Y=0,496$. Korelasi tersebut signifikan pada populasi. (3) Ada hubungan positif antara minat dan tingkat perhatian orang tua secara bersama-sama dengan hasil belajar IPS peserta didik, dengan koefisien korelasi $R=0,52 F_{\text {hit }}(27,04)>F_{\text {tab }}(3,07)$. Korelasi tersebut signifikan pada populasi.
\end{abstract}

Kata kunci: Minat, Tingkat Perhatian Orang Tua, Hasil Belajar.

\section{PENDAHULUAN}

Proses belajar mengajar tidak bisa lepas dari berbagai faktor yang mempengaruhi dan menunjang keberlangsungannya. Bagi lembaga pedidikan atau sekolah setelah menentukan program-program dan kurikulum pendidikan haruslah mempunyai prinsip dalam menentukan arah teknis pelaksanaan dari program dan kurikulum yang telah dicanangkan. Salah satu penunjang utamanya adalah minat belajar peserta didik. Minat belajar berperan sangat penting dalam kehidupan peserta didik dan mempunyai dampak yang besar terhadap sikap dan perilaku. Peserta didik yang berminat terhadap kegiatan belajar akan berusaha lebih keras dibandingkan peserta didik yang kurang berminat.

Selain minat belajar, perhatian orang tua dalam mengawasi belajar anaknya di rumah juga penting. Perhatian orang tua terhadap anakanaknya akan berpengaruh terhadap belajarnya dan minat belajar anak. Keluarga memiliki peran yang besar dalam menciptakan minat belajar bagi anak. Orang tua harus selalu siap sedia saat anak membutuhkan bantuan terlebih terhadap materi pelajaran yang sulit ditangkap oleh anak. Peralatan belajar yang dibutuhkan anak, juga perlu diperhatikan oleh orang tua.

Fenomena yang peneliti temukan setelah melakukan observasi di SMP Negeri 6 Palangka Raya pada kelas VIII berkaitan dengan minat belajar dan tingkat perhatian orang tua peserta didik dengan pelajaran IPS, peserta didik menunjukkan kurang kemauan atau keinginan peserta didik itu sendiri untuk mempelajari pelajaran IPS. Ketika peneliti melihat guru selesai 
menjelaskan materi dan melakukan tanya jawab terhadap materi yang telah dijelaskan di depan kelas masih banyak beberapa peserta didik yang tidak dapat menjawab pertanyaan yang telah diberikan guru dan bertanya jawaban kepada teman sebangkunya. Ini membuktikan peserta didik tidak fokus terhadap penjelasan yang telah diberikan guru. Ketika peneliti melakukan observasi dengan cara mengikuti kegiatan belajar mengajar di kelas VIII, peserta didik yang memperhatikan pelajaran hanya sedikit dan masih banyak peserta didik yang tidak memperhatikan pelajaran. Peneliti juga bertanya kepada beberapa peserta didik yang kurang mendapatkan perhatian dari orang tua dalam hal belajar di rumah. Peserta didik mengatakan bahwa orang tua mereka tidak pernah menanyakan pelajaran apa yang diperlajari di sekolah tadi, tidak pernah memeriksa buku catatan, tidak pernah memeriksa hasil nilai tugas maupun nilai ulangan harian dan orang tua tidak mengetahui jadwal pelajaran peserta didik disekolah.

Berdasarkan hasil pengamatan bahwa nilai ulangan harian di atas, peserta didik kelas VIII SMP Negeri 6 Palangka Raya Mata Pelajaran IPS Semester 2 terdapat 37\% tidak tuntas dan $63 \%$ tuntas serta nilai klasikal peserta didik kelas VIII adalah $80 \%$. Dengan demikian rendahnya hasil belajar peserta didik diduga oleh adanya minat belajar peserta didik yang kurang dalam mengikuti proses pembelajaran dan kurangnya perhatian orang tua dalam kegiatan belajar anak baik di sekolah maupun di rumah. Tujuan penelitian ini adalah untuk: 1) mengetahui hubungan positif minat belajar peserta didik dengan hasil belajar IPS peserta didik SMP
Negeri 6 Palangka Raya, 2) mengetahui hubungan positif tingkat perhatian orang tua dengan hasil belajar IPS peserta didik SMP Negeri 6 Palangka Raya, dan 3) mengetahui hubungan positif minat belajar dan tingkat perhatian orang tua secara bersama-sama dengan hasil belajar IPS peserta didik SMP Negeri 6 Palangka Raya.

Di sekolah-sekolah Amerika pengajaran IPS dikenal dengan social studies. Jadi, istilah IPS merupakan terjemahan social studies. Dengan demikian IPS dapat diartikan dengan "penelaahan atau kajian tentang masyarakat". Dalam mengkaji masyarakat, guru dapat melakukan kajian dari berbagai perspektif sosial, seperti kajian melalui pengajaran sejarah, geografi, ekonomi, sosiologi, antropologi, politik pemerintahan, dan aspek psikologi sosial yang disederhanakan untuk mencapai tujuan pembelajaran. (Cokrodikardjo, 2012) mengemukakan bahwa IPS adalah: perwujudan dari suatu pendekatan interdisipliner dari ilmu sosial. la merupakan integrasi dari berbagai cabang ilmu sosial yakni sosiologi, antropologi budaya, psikologi, sejarah, geokrafi, ekonomi, ilmu politik dan ekologi manusia, yang diformulasikan untuk tujuan instruksional dengan materi dan tujuan yang disederhanakan agar mudah dipelajari. Dengan demikian, IPS bukan ilmu sosial dan pembelajaran IPS yang dilaksanakan baik pada pendidikan dasar maupun pada pendidikan tinggi tidak menekankan pada aspek teoritis keilmuannya, tetapi aspek praktis dalam mempelajari, menelaah, mengkaji gejala, dan masalah sosial masyarakat, yang bobot dan keluasannya disesuaikan dengan jenjang pendidikan masing-masing. Berdasarkan pada 
falsafah negara tersebut di dalam Undangundang RI No. 20 Tahun 2003, maka telah dirumuskan tujuan pendidikan nasional, didalam SISDIKNAS (2005: 119) yaitu "bertujuan untuk berkembangnya potensi peserta didik agar menjadi manusia yang beriman dan bertaqwa kepada Tuhan Yang Maha Esa, berakhlak mulia, sehat, berilmu, cakap, kreatif, mandiri, dan menjadi Warga Negara demokratis serta bertanggung jawab".

Berkaitan dengan tujuan pendidikan di atas, tentu saja tujuan harus dikaitkan dengan kebutuhan dan disesuaikan dengan tantangantantangan kehidupan yang akan dihadapi peserta didik. Berkaitaan dengan hal tersebut pembelajaran IPS, bertujuan untuk: 1) mengajarkan konsep-konsep dasar sosiologi, geografi, ekonomi, sejarah, dan kewarganegaraan, pedagogis, dan psikologis, 2) mengembangkan kemampuan berpikir kritis dan kreatif, inkuiri, memecahkan masalah, dan keterampilan sosial, 3) membangun komitmen dan kesadaran terhadap nilai-nilai sosial dan kemanusiaan, dan 4) meningkatkan kemampuan bekerja sama dan berkompetisi dalam masyarakat yang majemuk, baik secara nasional maupun global.

Menurut Slameto (2010: 2) belajar ialah suatu proses usaha yang dilakukan seseorang untuk memperoleh suatu perubahan tingkah laku yang baru secara keseluruhan, sebagai hasil pengalamannya sendiri dalam interaksi dengan lingkungannya. Sedangkan menurut Whittaker (Djamarah, 2002: 12) belajar sebagai proses di mana tingkah laku ditimbulkan atau diubah melalui latihan atau pengalaman.

Hasil belajar adalah kemampuan- kemampuan yang dimiliki seorang siswa setelah ia menerima perlakukan dari guru. Sudjana (2002: 45) mengemukakan bahwa hasil belajar adalah kemampuan-kemampuan yang dimiliki peserta didik setelah menerima pengalaman belajarnya. Menurut Kingsley (Sudjana, 2005: 45) membagi tiga macam hasil belajar mengajar: 1) keterampilan dan kebiasaan, 2) pengetahuan dan pengarahan, dan 3). sikap dan cita-cita, yang masing-masing golongan dapat diisi dengan bahan yang ditetapkan dalam kurikulum sekolah". Dari pendapat di atas dapat disimpulkan bahwa hasil belajar adalah kemampuan keterampilan, sikap dan keterampilan yang diperoleh peserta didik setelah ia menerima perlakuan yang diberikan oleh guru sehingga dapat mengkonstruksikan pengetahuan itu dalam kehidupan sehari-hari.

Menurut Slameto (2010: 54) "faktor-faktor yang mempengaruhi belajar banyak jenisnya, tetapi dapat digolongkan menjadi dua saja, yaitu faktor intern dan faktor ekstern". Faktor intern adalah faktor yang ada dalam diri individu yang sedang belajar, sedangkan faktor ekstern adalah faktor yang ada di luar individu. Faktor-faktor Intern meliputi: a) kesehatan, adalah keadaan atau hal sehat. Kesehatan peserta didik berpengaruh terhadap belajarnya, b) intelegensi $(I Q)$, yaitu kesanggupan untuk menyesuaikan diri kepada kebutuhan baru, dengan menggunakan alat-alat berpikir yang sesuai dengan tujuannya., c) perhatian, yaitu keaktifan jiwa yang diarahkan kepada suatu objek, baik di dalam maupun di luar dirinya, d) bakat, adalah kemampun potensial yang dimiliki seseorang untuk mencapai keberhasilan pada masa yang akan datang, e) motif, adalah keadaan dalam pribadi orang yang 
mendorong individu untuk melakukan aktivitasaktivitas tertentu guna mencapai suatu tujuan, f) kematangan, adalah suatu tingkat atau fase dalam pertumbuhan seseorang dimana alat-alat tubuhnya sudah siap untuk melaksanakan kecakapan baru, dan g) kesiapan, adalah "kesediaan untuk memberi respon atau reaksi". Sedangkan Faktor-faktor ekstern meliputi: a) keluaga, cara orang tua mendidik anaknya besar pengaruhnya terhadap belajar anaknya. Purwanto (2006: 79) menyatakan bahwa "pendidikan keluarga adalah fundamen atau dasar dari pendidikan anak selanjutnya, b) sekolah, pengetahuan dan pengalaman yang diberikan melalui sekolah harus dilakukan dengan proses mengajar yang baik. Guru menyelenggarakan pendidikan dengan tetap memperhatikan kondisi anak didiknya, c) masyarakat, banyak kegiatan di dalam masyarakat yang dapat menumbuhkan minat belajar anak. Seperti kegiatan karang taruna ataupun kegiatan ekstrakulikuler sekolah.

Menurut Slameto (2010: 57) "minat adalah kecenderungan yang tetap untuk memperhatikan dan mengenang beberapa kegiatan. Kegiatan yang diminati peserta didik, akan diperhatikan terus-menerus yang disertai dengan rasa senang dan diperoleh rasa kepuasan". Menurut Baharuddin dan Wahyuni (2009: 25) Minat adalah "suatu rasa lebih suka dan rasa ketertarikan pada suatu hal atau aktivitas, tanpa ada yang menyuruh. Minat pada dasarnya adalah penerimaan akan suatu hubungan antara diri sendiri dengan sesuatu di luar diri. Semakin kuat atau dekat hubungan tersebut, semakin besar minat".

Tingkat perhatian orang tua adalah tingkat sejauh mana orang tua dalam membimbing dan bertanggungjawab mendidik anak agar memiliki sikap prilaku sopan dan hasil belajar yang baik dalam pelajaran. Orang tua adalah seorang yang dewasa yang mempunyai tanggung jawab atas putra-putrinya dan ia sebagai panutan serta tauladan dalam bertingkah laku. Suatu kesalahan besar apabila orang tua tidak memberikan perhatian kepada pertumbuhan dan perkembangan anak, sebab anak yang tumbuh tanpa perhatian orang tua akan menjadi anak yang jauh dari kasih sayang. Tidak lazim apabila orang tua membiarkan anaknya tumbuh dan berkembang tanpa ada dukungan dan motivasi walaupun secara materiil anak tidak membutuhkan namun dalam jiwa ia selalu mengharapkan kehadiran pendorong dan pemberi semangat. Tidak sedikit orang tua yang meninggalkan kesenangan pribadinya untuk membahagiakan atau menyenangkan anakanaknya, bahkan terkadang seorang ibu rela mengorbankan dirinya demi kepentingan anaknya. Dalam mengemukakan perhatian ini dapat ditempuh cara dengan menggolonggolongkan perhatian tersebut menurut cara tertentu. Perhatian orang tua apabila dikaitkan dengan macam-macam perhatian diatas, maka perhatian orang tua dapat diartikan sebagai pemusatan energi yang disengaja, intensif dan terkonsentrasi dari orang tua yang dilandasidari rasa penuh kesadaran, tanggung jawab dan kasih sayang dalam melakukan tindakan demi tercapainya hasil belajar yang memuaskan. Pengawasan dan pengarahan dari orang tua akan berpengaruh terhadap anak dalam mengikuti pembelajaran di sekolah khususnya dalam pembelajaran IPS.

Menurut Ihsan (2005: 63) ciri-ciri atau 
indikator orang tua yang memperhatikan adalah sebagai berikut: 1) membimbing anak dalam belajar, 2) mendorong anak untuk belajar, 3) bertanggung jawab mendidik dan membina anak secara terus menerus dengan cara memberikan pengarahan pentingnya belajar, dan 4) memperhatikan kebutuhan-kebutuhan yang menunjang pelajaran. Jadi dapat disimpulkan bahwa orang tua yang perhatian akan dengan senang hati akan memberikan perhatian kepada anak mereka dalam hal belajar agar dapat memperoleh hasil belajar yang baik dan prestasi yang bagus.

Minat belajar adalah suatu kemampuan umum yang dimiliki peserta didik untuk mencapai hasil belajar yang optimal yang dapat ditunjukan dengan kegiatan belajar. Dalam belajar diperlukan suatu pemusatan perhatian agar apa yang dipelajari dapat dipahami. Sehingga peserta didik dapat melakukan sesuatu yang sebelumnya tidak dapat dilakukan. Hasil belajar adalah hasil dari suatu kegiatan yang telah dikerjakan, atau diciptakan secara individu atau kelompok. Dengan kata lain peserta didik akan memperoleh hasil belajar setelah melakukan tes atau ujian yang diberikan oleh guru.

Minat sangat besar pengaruhnya terhadap hasil belajar, peserta didik yang tidak berminat terhadap pelajaran maka akan malas, dan tidak mau belajar dan memungkinkan akan memperoleh hasil belajar yang kurang baik. Berbeda dengan peserta didik yang memang berminat dengan pelajaran akan akan belajar bersunggu-sungguh dan dengan senang mempelajarinya dan akan memungkinkan peserta didik memperoleh hasil belajar yang baik. Selain minat belajar, peranan orang tua agar anaknya sukses dalam belajar di sekolah sebenarnya sangat besar bahkan bersifat menentukan. Dalam aktivitas belajar anak sering menemui kesulitan-kesulitan. Berbagai kesulitan itu harus diatasi agar pencapaian tujuan belajar secara optimal dapat diwujudkan. Upaya mengatasi berbagai kesulitan itu tidak cukup dibebankan kepada anak. Orang tua mempunyai tugas dan tanggungjawab untuk membantu meringankan atau mengatasi kesulitan yang dihadapi anak. Keterlibatan orang tua dalam menangani kesulitan belajar anak adalah dengan cara memberikan perhatian belajar kepada anak. Salah satu peran orang tua dalam upaya meningkatkan prestasi anaknya, adalah terjalinnya komunikasi atau interaksi edukatif yang secara disengaja mencurahkan perhatian kepada anaknya untuk mau belajar, bergairah, antusias, dan sungguh-sungguh. Karena perhatian orang tua merupakan tenaga psiskis yang dapat mendorong kegiatan belajar anaknya. Sehingga reaksi senang belajar, minat belajar, rajin dan sungguh-sungguh akan tumbuh pada diri anak yang pada gilirannya berkaitan erat dengan prestasi belajarnya. Dari uraian di atas, maka dapat disimpulkan bahwa minat dan tingkat perhatian orang tua dengan hasil belajar peserta didik cenderung memiliki hubungan positif dengan keberhasilan belajar seorang peserta didik.

Penelitian yang relevan dari penelitian sebelumnya yang dilakukan oleh Nyeneng (2008) dengan judul Hubungan Minat dan Cara Belajar Dengan Hasil Belajar Fisika Siswa Kelas XI IPA Semester Ganjil SMAN 1 KALIANDA Tahun Pelajaran 2007/2008. Hasil dianalisis diperoleh hubungan antara minat dengan hasil belajar yang sangat kuat dan signifikan. Ini dapat dilihat dari 
koefisien korelasi $(r=0,61)$ dan $t_{\text {hit }}(5,16)>$ $t_{\text {tab }}(2,42)$. Hubungan antara cara belajar dengan hasil belajar yaitu kuat dan signifikan yang mana dapat dilihat dari besarnya koefisien korelasi $(r$ $=0,52)$ dan $t_{\text {hit }}(3,93)>t_{\text {tab }}(2,42)$. Hubungan antara minat dan cara belajar dengan hasil belajar juga sangat kuat yang ditunjukkan oleh besarnya koefisien korelasi $(r=0,62)$ dan $F_{\text {hit }}(12,48)>$ $F_{\text {tab }}(5,16)$. Dari penelitian Mubarok (2007) dengan judul penelitian Pengaruh Perhatian Orang Tua dan Kelengkapan Sarana Belajar Terhadap Prestasi Belajar Mata Pelajaran Ekonomi Pada Siswa Kelas XI SMA Negeri Wanadadi Banjarnegara. Hasil penelitian menunjukkan bahwa pada hipotesis pertama yang menyebutkan ada pengaruh perhatian orang tua terhadap prestasi belajar siswa terbukti dengan ditunjukkan nilai koefisien regresi sebesar 2.713, diperkuat perhitungan nilai $\mathrm{t} X 1$ sebesar 4.004 sementara t tabel sebesar 2.000 atau (4.004 > 2.000) dengan nilai signifikansi sebesar $0.011<0.05$. Berdasarkan dua penelitian diatas, bahwa minat belajar dan tingkat perhatian orang tua sangat mempengaruhi hasil belajar peserta didik. Peserta didik yang memiliki minat akan dengan senang hati mempelajari pelajaran IPS dan peran orang tua dalam menumbuhkan minat dan semangat belajar anak juga sangat penting dalam meningkatkan prestasi belajar anak.

Hipotesis dalam penelitian ini sebagai berikut: 1) ada hubungan positif antara minat belajar dengan hasil belajar IPS peserta didik SMP Negeri 6 Palangka Raya, 2) ada hubungan positif antara tingkat perhatian orang tua dengan hasil belajar IPS peserta didik SMP Negeri 6 Palangka Raya, 3) ada hubungan positif antara minat belajar dan tingkat perhatian orang tua secara bersama-sama dengan hasil belajar IPS peserta didik SMP Negeri 6 Palangka Raya.

\section{METODE PENELITIAN}

Proses penelitian ini dilaksanakan selama 6 (enam) bulan, yaitu dari bulan Januari 2012 sampai dengan bulan Juni 2012. Penelitian ini dilaksanakan di SMP Negeri 6 Palangka Raya yang terletak di Jln. Let. Kol Seth Adji, Kelurahan Panarung, Kecamatan Pahandut Kota Palangka Raya, dengan nomor telepon (0536) 3224520. Pemilihan tempat penelitian ini didasarkan pada keterkaitan sekolah dengan judul penelitian yang diajukan oleh penulis. Metode yang digunakan dalam penelitian ini menggunakan metode penelitian korelasional. Karena penelitian ini berusaha menelaah hubungan antara satu variabel dengan variabel yang lainnya. Populasi dalam penelitian ini dikaitkan dengan pelajaran IPS, sehingga populasinya adalah jumlah keseluruhan peserta didik di kelas VIII SMP Negeri 6 Palangka Raya tahun ajaran 2011/2012 yang berjumlah 252 orang.

Untuk menentukan besar atau ukuran sampel minimal digunakan rumus Krejcie-Morgan, setelah dilakukan perhitungan diperoleh besar sampel yang diambil oleh peneliti dari populasi 252 peserta didik yang terdiri dari 8 kelas sebanyak $5 \%$ adalah 152 sampel. Sedangkan untuk teknik penarikan sampel sebanyak 152 peserta didik, digunakan teknik proportional random sampling yaitu berdasarkan tingkatan dengan jumlah yang terdiri dari kelas-kelas yang diambil sesuai proporsi yang ada dan dilakukan secara random.

Untuk menjaring data digunakan teknik pengambilan data berupa: angket (Kuesioner) dan 
tes. Angket dalam penelitian ini berbentuk angket tertutup. Pada kuesioner, peneliti telah memberikan beberapa alternatif jawaban yang pada kolom yang disediakan, sementara itu responden tinggal memilih dari jawaban yang ada yang paling mendekati pilihan responden. Adapun tujuan penggunaan angket dalam penelitian ini adalah untuk mengumpulkan data minat belajar peserta didik dan tingkat perhatian orang tua peserta didik kelas VIII SMP Negeri 6 Palangka Raya. Sehubungan dengan pemakaian angket dalam mengumpul data, maka data tersebut diskalakan dalam bentuk skor dengan skala Likert. Adapun skor penelitian angket minat belajar peserta didik dan tingkat perhatian orang tua peserta didik dalam penelitian dapat dilihat pada tabel 1 .

Teknik tes digunakan untuk memperoleh data hasil belajar peserta didik. Tes hasil belajar IPS yang digunakan berbentuk pilihan ganda dengan jumlah soal 30 soal. Skala pengukuran untuk hasil tes yang disebarkan, peneliti menggunakan skala Guttman, hal ini dilakukan untuk mempermudah peneliti melakukan penelitian dan menerapkan skor pada masingmasing jawaban responden. Pedoman penskoran dapat dilihat pada tabel 2.

Tabel 1. Skor Penelitian Angket Minat dan Tingkat Perhatian Orang Tua

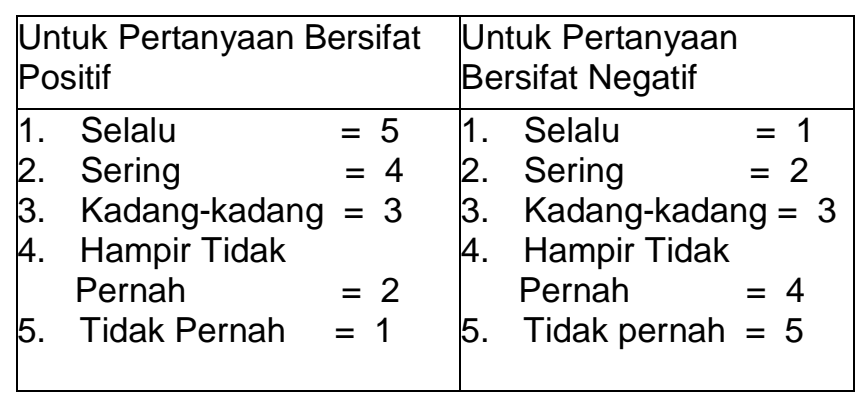

Tabel 2. Pedoman Penskoran Tes

\begin{tabular}{|c|c|c|}
\hline \multirow{2}{*}{ Pertanyaan } & \multicolumn{2}{|c|}{ Alternatif Jawaban } \\
\cline { 2 - 3 } & Benar & Salah \\
\hline Soal & 1 & 0 \\
\hline
\end{tabular}

Sebuah instrumen yang baik juga harus memenuhi persyaratan validitas dan reliabiltas. Karena itu sebelum instrumen digunakan harus di uji cobakan terlebih dahulu untuk menemukan validas dan reliabilitasnya. Subjek uji coba hendaknya diupayakan bukan subjek penelitian agar hasilnya benar- benar valid. Uji validitas tersebut digunakan untuk mengetahui apakah angket yang diberikan diluar, tapi masih dalam populasi tersebut valid atau tidak valid dan digunakan untuk menguji apakah item soal angket tersebut reliabel atau tidak. Berdasarkan perhitungan disimpulkan bahwa dari keseluruhan item soal angket yang berjumlah 30 item tersebut, terdapat beberapa item soal yang valid dan tidak valid, sehingga yang dinyatakan valid hitungan 29 item soal sedangkan yang tidak valid sebanyak 1 item soal. Dengan demikian, pada penelitian ini yang digunakan hanya 29 item soal yang valid tersebut. Perhitungan uji validitas tingkat perhatian orang tua menggunakan program SPSS versi 16.00 disimpulkan bahwa dari keseluruhan item angket dinyatakan valid sebanyak 23 item soal sedangkan yang tidak valid sebanyak 7 item soal. Dengan demikian, pada penelitian ini yang digunakan hanya 23 item soal yang valid tersebut. Sedangkan Perhitungan uji validitas tes hasil belajar IPS menggunakan program ITEMAN disimpulkan bahwa dari keseluruhan item soal tes hasil belajar yang berjumlah 30 item tersebut, terdapat beberapa item soal yang daya 
pembedanya diterima dengan baik dan daya pembeda yang kurang baik, sehingga yang dinyatakan baik sebanyak 26 item soal sedangkan yang tidak baik sebanyak 4 item soal. Dengan demikian pada penelitian ini, tes hasil belajar yang digunakan hanya 26 item soal yang daya pembedanya diterima dengan baik tersebut. Kuesioner dalam penelitian ini perlu diuji kebenaranya untuk mendapatkan petunjuk mengenai mutu penelitian. Uji reliabilitas dilakukan terhadap item pertanyaan yang valid. Hasil penelitian yang reliabel, bila terdapat kesamaan data dalam waktu yang berbeda. Menurut Sugiyono (2010:173) "instrumen yang reliabel adalah instrumen yang bila digunakan beberapa kali untuk mengukur obyek yang sama, akan menghasilkan data yang sama. Untuk menguji instrumen ini peneliti menggunakan rumus Alpha Cronbach. Perhitungan uji reliabilitas variabel minat belajar ini menggunakan program SPSS versi 16.00. Dari 30 item angket yang di uji coba diperoleh hasil yang reliabel 29 item yang dinyatakan valid. Dan diperoleh hasil perhitungan Alpha Cronbach adalah 0,902 . Perhitungan uji reliabilitas variabel tingkat perhatian Orang Tua ini menggunakan program SPSS versi 16.00. Dari 30 item angket yang di uji coba diperoleh hasil yang reliabel 23 item yang dinyatakan valid. Dan diperoleh hasil perhitungan Alpha Cronbach adalah 0,859 . Untuk perhitungan uji reliabilitas variabel hasil belajar IPS menggunakan ITEMEN. Adapun hasil reliabilitas dari 26 item soal yang baik didapat hasil Alpha Cronbach adalah 0,625 .

Teknik analisis data yang digunakan untuk penelitian ini peneliti menggunakan rumus analisis data Product Moment dan korelasi ganda.
Adapun penyelesaian penelitian ini menempuh langkah-langkah sesuai pula dengan prosedur analisis yang digunakan dalam Rumus Korelasi Product Moment dan korelasi ganda. Teknik korelasi ini dikembangkan oleh Karl Pearson. Korelasi ganda (multiple correlation) adalah korelasi antara dua atau lebih variabel bebas secara bersama-sama dengan suatu varibel terikat. Angka yang menunjukan arah dan besar kuatnya hubungan antara dua atau lebih variabel bebas dengan satu variabel terikat disebut koefisien korelasi ganda, dan biasa disimbol R.

\section{Hasil Penelitian dan Pembahasan}

Jumlah peserta didik kelas VIII SMP Negeri 6 Palangka Raya Semester genap tahun ajaran 2011/2012 yang dijadikan populasi terdiri dari 8 kelas yaitu kelas VIII-1 sampai VIII-8 yang total peserta didiknya berjumlah 252 orang peserta didik dan yang di jadikan sampel berjumlah 152 orang peserta didik. Setelah dilaksanakan pengumpulan data dengan menggunakan angket sebanyak 29 item untuk data minat belajar peserta didik di kelas VIII SMP Negeri 6 Palangka Raya diperoleh hasil penelitian bahwa skor terendah sebesar 32 dan skor tertinggi adalah 112, dengan rata-rata skor f.xi $/ \mathrm{N}=13203 / 152=86,86$. Adapun untuk lebih lengkapnya dapat dilihat pada tabel 3.

Dari perhitungan di atas, di peroleh persentase kecenderungan variabel minat belajar peserta didik di kels VIII SMP Negeri 6 Palangka Raya skor terendah 32 dan skor tertinggi 112. Rerata ideal (Mi) 87 dan simpangan baku ideal (SDi) 19,33. Hasil perhitungan minat belajar peserta didik SMP Negeri 6 Palangka Raya dapat dilihat pada tabel 4 . 
Tabel 3. Distribusi Frekuensi Skor Minat Belajar Peserta didik Kelas VIII SMP Negeri 6 Palangka Raya

\begin{tabular}{|c|l|c|c|c|c|l|}
\hline No & Interval & $\begin{array}{c}\text { Frekuensi } \\
(\mathrm{f})\end{array}$ & $\begin{array}{l}\text { Frekuensi } \\
\text { kumulatif }\end{array}$ & $\begin{array}{c}\text { Titik Tengah } \\
(\mathrm{xi})\end{array}$ & f.xi & \multicolumn{1}{|c|}{ f.xi } \\
\hline 1. & $32-40$ & 6 & 6 & 36 & 216 & 46656 \\
\hline 2. & $41-49$ & 22 & 28 & 45 & 990 & 980100 \\
\hline 3. & $50-58$ & 4 & 32 & 54 & 216 & 46656 \\
\hline 4. & $59-67$ & 1 & 33 & 63 & 63 & 3969 \\
\hline 5. & $68-76$ & 2 & 35 & 72 & 144 & 20736 \\
\hline 6. & $77-85$ & 6 & 41 & 81 & 486 & 236196 \\
\hline 7. & $86-94$ & 20 & 61 & 90 & 1800 & 3240000 \\
\hline 8. & $95-103$ & 60 & 121 & 99 & 5940 & 35283600 \\
\hline 9. & $104-112$ & 31 & 152 & 108 & 3348 & 11209104 \\
\hline & & $\mathrm{f}=152$ & & & f.xi $=13203$ & 51067017 \\
\hline
\end{tabular}

Tabel 4. Kategori Minat Belajar Peserta Didik

\begin{tabular}{|c|l|l|c|l|}
\hline \multicolumn{1}{|c|}{ Interval } & \multicolumn{1}{c|}{ Skor } & Kategori & Frekuensi & Persentase \\
\hline (Mi-Sdi) ke bawah & 68 ke bawah & Rendah & 33 & $21,71 \%$ \\
\hline (Mi-Sdi) s.d (Mi+Sdi) & $69-105$ & Sedang & 105 & $69,08 \%$ \\
\hline (Mi+Sdi) & 106 ke atas & Tinggi & 14 & $9,21 \%$ \\
\hline \multicolumn{2}{|l}{ Jumlah } & 152 & $100 \%$ \\
\hline
\end{tabular}

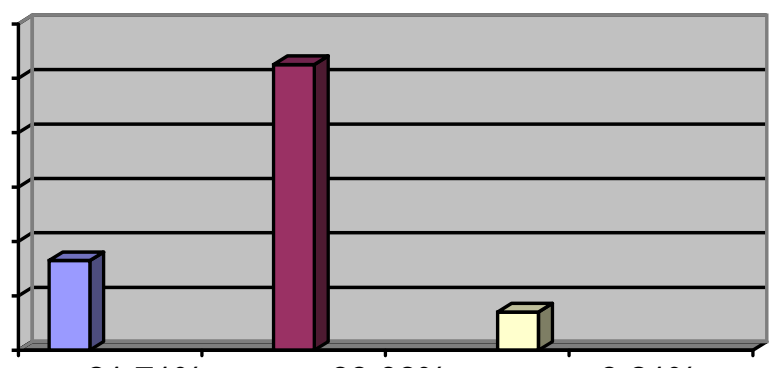
$21,71 \%$
$69,08 \%$
$9,21 \%$

Gambar 1. Kategori Diagram Batang Minat Belajar Peserta didik

Tabel 5 . Distribusi Frekuensi Skor Tingkat Perhatian Orang Tua Peserta didik Kelas VIII SMP Negeri 6 Palangka Raya

\begin{tabular}{|l|l|c|c|c|c|l|}
\hline No & Interval & Frekuensi (f) & $\begin{array}{l}\text { Frekuensi } \\
\text { kumulatif }\end{array}$ & $\begin{array}{c}\text { Titik Tengah } \\
(\mathrm{xi})\end{array}$ & $\mathrm{f} . \mathrm{xi}$ & \multicolumn{1}{|c|}{$\mathrm{xi}^{2}$} \\
\hline 1. & $35-41$ & 8 & 8 & 38 & 304 & 92416 \\
\hline 2. & $42-48$ & 15 & 23 & 45 & 675 & 455625 \\
\hline 3. & $49-55$ & 7 & 30 & 52 & 364 & 132496 \\
\hline 4. & $56-62$ & 7 & 37 & 59 & 413 & 170569 \\
\hline 5. & $63-69$ & 5 & 42 & 66 & 330 & 108900 \\
\hline 6. & $70-76$ & 28 & 70 & 73 & 2044 & 4177936 \\
\hline 7. & $77-83$ & 46 & 116 & 80 & 3680 & 13542400 \\
\hline 8. & $84-90$ & 31 & 147 & 87 & 2697 & 7273809 \\
\hline 9. & $91-97$ & 5 & 152 & 94 & 470 & 220900 \\
\hline & & $\mathrm{f}=152$ & & & 10977 & 26175051 \\
\hline
\end{tabular}


Tabel 6 . Kategori Tingkat Perhatian Orang Tua Peserta Didik

\begin{tabular}{|l|l|l|c|l|}
\hline \multicolumn{1}{|c|}{ Interval } & \multicolumn{1}{|c|}{ Skor } & Kategori & Frekuensi & Persentase \\
\hline (Mi - Sdi) ke bawah & 54 ke bawah & Rendah & 28 & $18,42 \%$ \\
\hline (Mi-Sdi) s.d (Mi+Sdi) & $55-83$ & Sedang & 88 & $57,90 \%$ \\
\hline (Mi+Sdi) & 84 ke atas & Tinggi & 36 & $23,68 \%$ \\
\hline \multicolumn{3}{|c|}{ Jumlah } & 152 & $100 \%$ \\
\hline
\end{tabular}

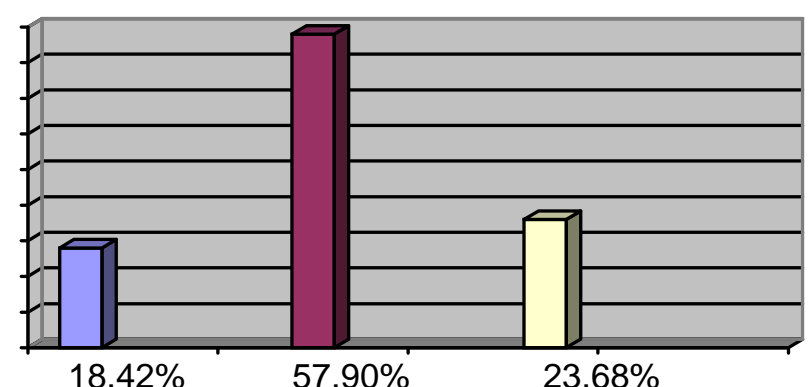

Gambar 2 . Kategori Diagram Batang Tingkat Perhatian Peserta didik

Tabel 7 . Distribusi Frekuensi Skor Hasil Belajar IPS Peserta didik Kelas VIII SMP Negeri 6 Palangka Raya

\begin{tabular}{|l|c|c|c|c|c|}
\hline No & Interval & Frekuensi (f) & Frekuensi kumulatif & f.xi & $f^{x^{2}}$ \\
\hline 1. & 10 & 1 & 1 & 10 & 100 \\
\hline 2. & 11 & 2 & 3 & 22 & 484 \\
\hline 3. & 12 & 1 & 4 & 12 & 144 \\
\hline 4. & 13 & 3 & 7 & 39 & 1521 \\
\hline 5. & 14 & 4 & 11 & 56 & 3136 \\
\hline 6. & 15 & 3 & 14 & 45 & 2025 \\
\hline 7. & 17 & 3 & 17 & 51 & 2601 \\
\hline 8. & 18 & 6 & 23 & 108 & 11664 \\
\hline 9. & 19 & 15 & 38 & 285 & 81225 \\
\hline 10. & 20 & 24 & 62 & 480 & 230400 \\
\hline 11. & 21 & 39 & 101 & 819 & 670761 \\
\hline 12. & 22 & 29 & 130 & 638 & 407044 \\
\hline 13. & 23 & 18 & 148 & 414 & 171396 \\
\hline 14. & 24 & 4 & 152 & 96 & 9216 \\
\hline & & $\mathrm{f}=152$ & & 3075 & 1591717 \\
\hline
\end{tabular}

Tabel 8 . Kategori Hasil Belajar Peserta Didik

\begin{tabular}{|l|l|l|c|c|}
\hline Interval & Skor & Kategori & Frekuensi & Persentase \\
\hline (Mi - Sdi) ke bawah & 9 ke bawah & Rendah & 0 & $0 \%$ \\
\hline (Mi-Sdi) s.d (Mi+Sdi) & $10-16$ & Sedang & 14 & $9,21 \%$ \\
\hline (Mi+Sdi) & 17 ke atas & Tinggi & 138 & $90,79 \%$ \\
\hline \multicolumn{2}{|c|}{ Jumlah } & 152 & $100 \%$ \\
\hline
\end{tabular}


Berdasarkan tabel di atas, dapat dinyatakan bahwa minat belajar peserta didik kelas VIII SMP Negeri 6 Palangka Raya dikatakan kategori rendah sebesar $21,71 \%$, kategori sedang sebesar 69,08\% sedangkan kategori tinggi sebesar $9,21 \%$ dengan demikian dapat diketahui gambaran minat belajar peserta didik di kelas VIII SMP Negeri 6 Palangka Raya dikatakan kategori sedang. Setelah dilaksanakan pengumpulan data dengan menggunakan angket sebanyak 23 item untuk data tingkat perhatian orang tua peserta didik di kelas VIII SMP Negeri 6 Palangka Raya diperoleh hasil penelitian bahwa skor terendah sebesar 35 dan skor tertinggi adalah 97, dengan rata-rata skor f.xi/ $\mathrm{N}=10977: 152=72,22$. Adapun untuk lebih lengkapnya dapat dilihat pada tabel 5 .

Dari perhitungan di atas, di peroleh persentase kecenderungan variabel tingkat perhatian orang tua peserta didik di kelas VIII SMP Negeri 6 Palangka Raya skor terendah 35 dan skor tertinggi 97. Rerata ideal (Mi) 69 dan simpangan baku ideal (SDi) 15,33. Hasil perhitungan dapat dilihat pada tabel 6 .

Berdasarkan tabel di atas, dapat dinyatakan bahwa tingkat perhatian orang tua peserta didik kelas VIII SMP Negeri 6 Palangka Raya dikatakan kategori rendah sebesar $18,42 \%$, kategori sedang sebesar $57,90 \%$ sedangkan kategori tinggi sebesar 23,68\% dengan demikian dapat diketahui gambaran tingkat perhatian orang tua peserta didik di kelas VIII SMP Negeri 6 Palangka Raya dikatakan kategori sedang.

Berdasarkan tes mata pelajaran IPS di kelas VIII dari 152 peserta didik yang dijadikan objek penelitian maka diperoleh skor terendah sebesar 10 dan skor tertinggi sebesar 24 dengan rata-rata skor f.xi/ $\mathrm{N}=3075: 152=20,23$ dapat dilihat pada tabel 7.

Berdasarkan perhitungan pada tabel diperoleh skor terendah 10 dan skor tertinggi 24, dengan rerata ideal $(\mathrm{Mi}) 13$ dan simpangan baku ideal (SDi) 4,33 (perhitungan selengkapnya dapat dilihat pada lampiran). Hasil perhitungan yang menunjukan kategori hasil belajar IPS yang dapat dilihat pada tabel 8

Berdasarkan tabel di atas, dapat dinyatakan bahwa hasil belajar peserta didik kelas VIII SMP Negeri 6 Palangka Raya dikatakan kategori rendah sebesar $0 \%$, kategori sedang sebesar $9,21 \%$ sedangkan kategori tinggi sebesar 90,79\% dengan demikian dapat diketahui gambaran hasil belajar peserta didik di kelas VIII SMP Negeri 6 Palangka Raya dikatakan kategori tinggi.

Setelah peneliti dapatkan hasil dari data di lapangan yang telah memenuhi kriteria validitas, reliabilitas maka dapat diteruskan untuk pengujian selanjutnya yaitu untuk mengetahui hubungan antarvariabel dan dibantu dengan tabel penolong seperti yang terlampir. Dalam menganalisis data penelitian ini peneliti menggunakan rumus Korelasi Product Moment Pearson dan Korelasi Ganda. Analisis ini dimaksudkan untuk mengetahui hubungan minat dan tingkat perhatian orang tua dengan hasil belajar IPS peserta didik di SMP Negeri 6 Palangka Raya.

Berdasarkan perhitungan diperoleh nilai $\mathrm{rX1Y}=0,521$ sedangkan rtabel pada $\alpha=5 \%$ dan db (152- 2=150). Uji satu pihaknya adalah rtabel $=0,135$ sehingga $r x y>$ rtabel atau 0,521 $>0,135$ Ho ditolak (Ha diterima). Dengan demikian dapat disimpulkan bahwa pada populasi 
ada hubungan positif antara minat belajar dengan hasil belajar IPS di SMP Negeri 6 Palangka Raya. Adapun besarnya sumbangan terhadap variabel $0,521^{2} \times 100 \%=27,14 \%$, yang menyatakan bahwa minat belajar mempengaruhi hasil belajar IPS peserta didik SMP Negeri 6 Palangka Raya sebesar $27,14 \%$ dan sisanya $72,86 \%$ dipengaruhi oleh variabel lain. Berdasarkan perhitungan diperoleh nilai $\mathrm{rX2Y}=0,496$ sedangkan rtabel pada $\alpha=5 \%$ dan db (152- $2=150)$. Uji satu pihaknya adalah rtabel $=0,135$ sehingga $r x y>$ rtabel atau 0,496 > 0,135 $\mathrm{Ho}$ ditolak $(\mathrm{Ha}$ diterima). Dengan demikian dapat disimpulkan bahwa pada populasi ada hubungan positif antara tingkat perhatian dengan hasil belajar IPS di SMP Negeri 6 Palangka Raya. Adapun besarnya sumbangan terhadap variabel $0,496^{2} \times 100 \%=$ $24,60 \%$, yang menyatakan bahwa tingkat perhatian orang tua mempengaruhi hasil belajar IPS peserta didik SMP Negeri 6 Palangka Raya sebesar $24,60 \%$ dan sisanya $75,40 \%$ dipengaruhi oleh variabel lain. Dari perhitungan analisis data untuk mencari nilai $\mathrm{rX1Y}$, rX2Y, dan rX1X2 didapat hasilnya sebesar $\quad r X 1 Y=0,521$ hasil $r X 2 Y=0,496$ dan $r X 1 X 2=0,894$. Apabila dari hasil perhitungan $\mathrm{rX}_{1 \mathrm{Y}}, \quad \mathrm{rX} 2 \mathrm{Y}$, dan $\mathrm{rX} 1 \mathrm{X} 2$ diatas dimasukan ke dalam korelasi ganda menhasilkan $\mathrm{R}=0,52$. Adapun besarnya sumbangan terhadap variabel $0,52^{2} \times 100 \%=$ $27,04 \%$, yang menyatakan bahwa minat belajar dan tingkat perhatian orang tua mempengaruhi hasil belajar IPS peserta didik SMP Negeri 6 Palangka Raya sebesar 27,04\% dan sisanya $72,96 \%$ dipengaruhi oleh variabel lain.

Kaidah pengujian signifikansi dengan uji
F. Setelah dihitung ternyata Fhitung $>F_{\text {tabel }}$ atau 27,04 > 3,07 maka Ho ditolak (Ha diterima) artinya terdapat hubungan positif antara minat dan tingkat perhatian orang tua secara bersamasama dengan hasil belajar IPS peserta didik di SMP Negeri 6 Palangka Raya.

Berdasarkan data yang telah didapatkan, dimasukan dalam perhitungan korelasi ganda dengan koefisien $R=0,52$ hasil uji signifikansi Fhitung > Ftabel atau 27,04 > 3,07 maka Ho ditolak (Ha diterima) artinya terdapat hubungan positif antara minat dan tingkat perhatian orang tua secara bersama-sama dengan hasil belajar IPS peserta didik di SMP Negeri 6 Palangka Raya. Hal ini berarti apabila minat dan tingkat perhatian orang tua peserta didik semakin tinggi maka hasil belajar IPS peserta didik akan semakin tinggi. Koefisien diterminasi untuk minat belajar sebesar $0,521^{2} \times 100 \%=$ $27,14 \%$, yang menyatakan bahwa minat belajar mempengaruhi hasil belajar IPS peserta didik SMP Negeri 6 Palangka Raya sebesar 27,14\% dan sisanya $72,86 \%$ dipengaruhi oleh variabel lain dan sisanya $72,86 \%$ dipengaruhi oleh variabel lain. Koefisien diterminasi untuk tingkat perhatian orang tua sebesar $0,496^{2} \times 100 \%=24,60 \%$, yang menyatakan bahwa tingkat perhatian orang tua mempengaruhi hasil belajar IPS peserta didik SMP Negeri 6 Palangka Raya sebesar 24,60\% dan sisanya $75,40 \%$ dipengaruhi oleh variabel lain. Adapun koefisien diterminasi minat dan tingkat perhatian orang tua $0,52^{2} \times 100 \%=$ $27,04 \%$, yang menyatakan bahwa minat belajar dan tingkat perhatian orang tua mempengaruhi hasil belajar IPS peserta didik SMP Negeri 6 Palangka Raya sebesar 27,04\% dan sisanya 
$72,96 \%$ dipengaruhi oleh variabel lain.

\section{KESIMPULAN}

Dari penelitian yang dilakukan dan hasil yang diperoleh maka penelitian ini dapat disimpulkan: 1) ada hubungan positif antara minat belajar dengan hasil belajar IPS peserta didik, dengan koefisien korelasi $r X 1 Y=0,521$. Korelasi tersebut signifikan pada populasi. Hal ini berarti apabila minat belajar peserta didik semakin tinggi maka hasil belajar IPS peserta didik akan semakin tinggi begitu pula sebaliknya, 2) ada hubungan positif antara tingkat perhatian orang tua dengan hasil belajar IPS peserta didik, dengan koefisien korelasi $r X 2 Y=0,496$. Korelasi tersebut signifikan pada populasi. Hal ini berarti apabila tingkat perhatian orang tua semakin tinggi maka hasil belajar IPS peserta didik akan semakin tinggi begitu pula juga sebaliknya, 3) ada hubungan positif antara minat dan tingkat perhatian orang tua secara bersama-sama dengan hasil belajar IPS peserta didik, dengan koefisien korelasi $R=0,52$ Fhit(27,04) > Ftab(3,07). Korelasi tersebut signifikan pada populasi. Hal ini berarti apabila minat dan tingkat perhatian orang tua semakin tinggi maka hasil belajar IPS peserta didik akan semakin tinggi begitu pula sebaliknya.

\section{DAFTAR PUSTAKA}

Burhanuddin \& Wahyuni. 2000. Kamus Besar Bahasa Indonesia. Jakarta: DEPDIKBUD.

Djamarah, S.B. 2002. Psikologi Belajar. Jakarta: Rineka Cipta. TIM. 2008. Buku Pedoman Penulisan Skripsi. UMP.

Ikhsan, F. 2005. Dasar-Dasar Kependidikan. Jakarta: PT. Rineka Cipta.
Mubarok,

M.

Z. 2007.

(http://www.google.com/pdf.

Pengaruh-Perhatian-Orang- Tua-danKelengkapan-Sarana-BelajarTerhadap-Prestasi-Belajar) 6 Maret 21.

$\begin{array}{llll}\text { Nyeneng, } & \text { I } & \text { D. } & \text { P. } \\ 2008\end{array}$ (http://www.scribd.com/doc/2381705/h ubungan-minat- dan-cara-belajardengan-hasil-belajar-fisika-siswakelas-xi-ipa-semester-ganjil-sman-1) 6 Maret 2012

Purwanto, N. 2006. Ilmu Pendidikan Teoritis dan Praktis. Bandung: PT. Remaja Rosdakarya.

Slameto. 2010. Belajar dan Faktor-faktor yang Mempengaruhinya. Jakarta: Rineka Cipta.

Sudjana, N. 2005. Dasar-dasar Proses Belajar Mengajar. Bandung: Sinar Baru Algensindo.

Sugiyono. 2010. Metode Penelitian. Pendidikan Pendekata Kuantitatif, Kualitatif, dan $R \& D$. Bandung: Alfabeta. 